\title{
The Moderating Effect of Tourism By-Products on the Relationship between Tourism Core Products and Destination Image (Sarawak, Malaysia)
}

\author{
Mohd Salehuddin Mohd Zahari ${ }^{\mathrm{A}}$, Mohd Hafiz Hanafiah ${ }^{\mathrm{A}}$, Emaria Ahmad ${ }^{\mathrm{B}}$, Nur Adilah Md Zain ${ }^{\mathrm{C}}$ \\ Received: April 6, 2017 | Revised: May 30, 2017 | Accepted: August 10, 2017
}

DOI: 10.5937/gp21-16079

\begin{abstract}
This paper reports an empirical investigation on the moderating effects of the tourism by- products in building Sarawak destination image. Using causal research design through a quantitative method, selfreported and self-administered questionnaire, this study surveyed international tourists who had visited Sarawak and experienced the state core tourism products which include purchasing the local tourism by-products. Through the descriptive and inferential statistics, some useful insights about the issue investigated were significantly obtained. It's interesting to note that besides experiencing the tourism core products, the Sarawak Tourism by-products are also catching the international tourist's attention. The moderating effect of tourism by-products on the relationship between tourism core products (culture, adventure, and nature) and Sarawak destination image was empirically confirmed. In fact, in addition to the core culture, adventure and nature product, the local tourism by- products undeniably building and strengthening the image of Sarawak as a tourist destination. This promising indication is, therefore, should not be ignored by the state government, tourism authority, tour operators, the local government, hotels and other related local authorities.
\end{abstract}

Keywords: Tourism by-products, culture, adventure, nature, destination image

\section{Introduction}

No doubt image of a destination is one of the important determinants that influence tourists in deciding to choose a particular holiday destination (Horner, Swarbrooke, 2016; Hosany, et al., 2007; Usakli, Baloglu, 2011). This connotation has encouraged many countries, specifically tourism authorities and tourism destinations to continuously develop or sustain their image among the tourists (Bornhorst, et al., 2010; Buhalis, 200o; Pike, Page, 2014). Tourism scholars postulated that the destination image is formed based on the three distinc- tive components, namely cognitive, affective and conative (Agapito, et al., 2013; Roth, Diamantopoulos, 2009; Ryan, Cave, 2005; White, 2014). On cognitive or perceptual elements, the image is evaluated through the ideas, knowledge, and beliefs of the individual have toward all attributes of a destination. In this sense, the image of a destination is assessed by the attributes relate to its resources and attractions in which influence tourists travel and experience (Beerli, Martin, 2004; Gallarza, et al., 2002; Tasci, Gartner, 2007; Zhang, et al., 2014). Affective element on the other hand is refer-

\footnotetext{
A Faculty of Hotel and Tourism Management, Universiti Teknologi MARA, 40450 Shah Alam, Selangor Darul Ehsan, Malaysia

B Nusantara Institute of Information Technology College, Lot 2765, Block 10, Jalan Tun Ahmad Zaidi Adruce, 93150, Kuching, Sarawak

c School of Geosciences, University of Sydney, Australia

* Corresponding author: Mohd Hafiz Hanafiah, e-mail:hafizhanafiah@salam.uitm.edu.my
} 
ring to the feelings or emotional dimension that a person has toward the tourism destination (Zhang, et al., 2014). Beerli and Martin (2004) argue that emotional dimensions or components are strongly influencing the motivations of tourists to travel to a specific destination. Lastly the conative component represents action such as the individual's action to revisit the destination or even recommend it to others (Agapito, et al., 2013; Tasci, et al., 2007).

Tasci and Kozak (2006) classified the attributes of a destination image into two major tourism core products namely the primary and the secondary products. The primary includes natural features such as natural resources, scenery, climate, culture, ecology, historical, architectural and many others while secondary includes human-made features that are built either by the government, tourism authorities, individuals and private sectors such as resorts, transportation, hotels, entertainment and catering outlets. These tourism core products and its characteristics plus services and intangible products strongly influenced the image of a tourist destination (Brijs, et al., 2011; Wang, et al., 2012).

Although the relationship between tourism core products and the destination images have been widely discussed and recognized (Horner, Swarbrooke, 2016; McCartney, et al., 2008; Mehmetoglu, Normann, 2013; Ortega, Rodríguez, 2007), the understanding of the contribution of the complementary attributes in improving destination image is lacking thus need to be further explored (Chen, Phou, 2013; Pike, Page, 2014). In this case, Prebensen (2007), Elliot and Papadopoulos (2016) and $\mathrm{Xu}$ (2010) contends that besides tourism core products, its by-products like local souvenirs, eth- nic crafts, miniatures, food products and merchandise that represents, synonym and portraying a particular destination could also contribute to increasing and strengthening the tourism destination image. Vladimir, a city in Russia, for instance, not only attracts a substantial number of international tourists because of its culture and architectural sights. However, the unique local crafts without exception contribute to the image of a city (Volkov, 2010). In addition, the local tourism by-products have also created the image of Turkey as a preferred tourism destination amid the international tourists from all over the world (Budnarowska, 2012; Yüksel, Akgül, 2007) and in fact Zhang et al. (2014) in their study entitled "Destination image and tourist loyalty: A meta-analysis" posits the local tourism by-products in addition to the tourism core products could moderate the image of a particular destination or country. Despite the above notion, there is still unclear understanding of how the local tourism by-products affect to the Sarawak tourism image.

\section{Issues}

In line with the preceding notion, out of many states in Malaysia, Sarawak which is also known as Bumi Kenyalang or Lands of the Hornbills is rich in diversification of primary tourism products, namely natural landscape, diverse culture, heritage and nature plus other products like longhouses, caves, national parks, mountain, forest, wildlife, exotic foods and many others. Owing to the diversification of the primary tourism products, the Sarawak Tourism Board (2014) started to promote its tourism core products like cul-

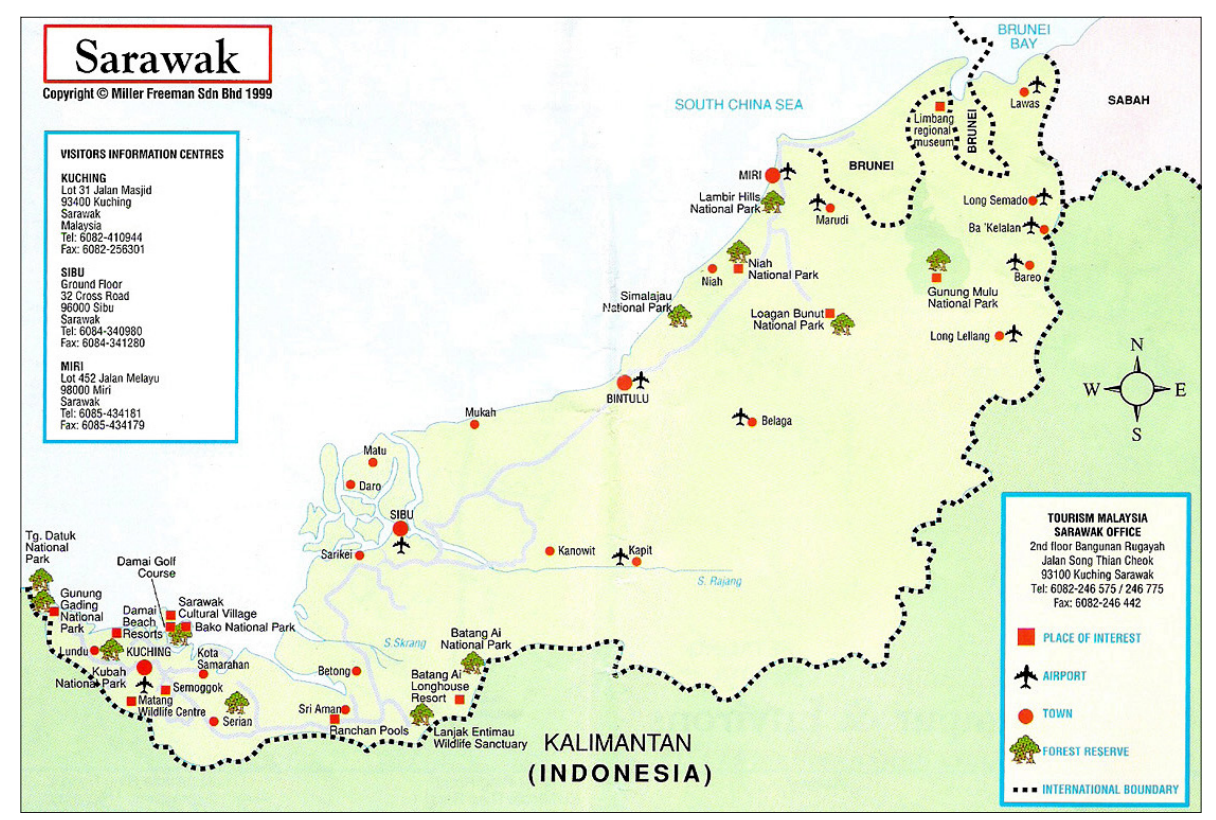

Figure 1. Map of Sarawak

Source: Researcher 
ture, adventure and nature or just known as CAN to the local and international tourists (Ban, Ramsaran, 2017). These core or Sarawak signature tourism products are claimed to have a strong influenced in attracting the international tourists. The Ministry of Tourism Sarawak (2016) reported that a positive growth of tourist arrivals apparent both from the domestic and international commencing with the 3,270,655 in 2010 to more than $4,517,179$ in 2015 and the figure is expected to flourish yearly. Figure 1 below is the map that illustrates the available tourism product of Sarawak.

According to Datuk Amar Abang Haji Abdul Rahman Zohari, the Minister of Tourism Sarawak, the excellent range of tourism products together with the promotions and advertisements directly establishing Sarawak as one of the globals recognized culture, adventure and nature tourism destination (Borneo Post, 2014). A total of 431,505 tourists visited the sixteen Sarawak national parks in 2012, meanwhile the Sarawak Cultural Village (SCV) has remained a popular tourist attraction for more than two decades (MOTS, 2014). Not too harsh to say that this positive scenario indicates these three core or signature tourism products (culture, adventure and nature tourism) continuously building or strengthening the image of Sarawak as a tourism destination among the international tourists.

Apart from this, scholars argued that tourists when travelling to any destination in addition to the tourism core activities will also take the opportunity to get and purchase the local tourism by-products that synonymous with the destination (Kim, Littrell, 2001; Paraskevaidis, Andriotis, 2015; Reisinger, Turner, 2000; Wong, Cheng, 2014). To some of the tourists, buying the local tourism by-products is one of the memories for them to stay in contact with the destination or in another word as the symbols of a destination that they have visited (Wong, Cheng, 2014). In this sense, it is argued and based on what has been highlighted by Yin, Poon, and Su (2017) and Wong and Cheng (2014), the local tourism by-products of a particular destination could also contribute to increasing and strengthening the tourism image of the destination.

In line with this notion and the case of Sarawak, the international tourists who visited this state also to ex- perience the culture, adventure and nature as the state tourism core products are assumed to have purchased the favorite local by-products. Accoridng to Bojei and Sahari (2015), Sarawak is rich with the uniqueness and originality of the local by-products such as the local souvenirs (e.g. key chains and others), ethnic crafts (e.g. hand-woven Pua Kumbu, Sarawak mats, blowpipes, batik textile, pottery, wood carvings, bamboo, rattan baskets, bead work, fabrics, furniture, tree bark, sumpit, sape and others), miniatures (e.g. the replica of the riverboats/perahu tambang, the longhouse, the baruk/head house of the Bidayuh community and others), food products (e.g. ikan terubok, kek lapis Sarawak, Sarawak black/white pepper, traditional local foods and others) and other merchandise that related to the Land of Hornbills.

Despite the above notion, compared to culture, adventure, and nature (CAN), there is still unclear understanding of how and to what extent that the local tourism by-products contribute to the Sarawak tourism image (Chin, et al., 2016; Jamaludin, et al., 2012; Musa, Thirumoorthi, 2016). In other words, besides the core tourism products what is the moderating effect of the local tourism by-products in building the image of Sarawak as a tourism destination? In fact, there has been a very limited analysis looking at the relationship between the tourism by-products and tourism destination image (Agapito, et al., 2013; Bojei, Sahari, 2015; Elliot, Papadopoulos, 2016; Lin, Mao, 2015; Mehmetoglu, Normann, 2013; Wang, et al., 2012) and to date none is looking it from the Malaysian perspective. Thus, to answer the highlighting issue and to fill the research gap, this study examines the moderating effect of the local tourism by-products in building Sarawak destination image as per depicted in Figure 1.

Through the study framework, the primary objective is further supported with two main hypotheses and three sub-hypotheses.

$\mathrm{H}_{1}$ : There is a significant relationship between tourism core products and destination image.

$\mathrm{H}_{1 \mathrm{a}}$ : There is a significant relationship between cultural attributes as tourism core products and destination image.

$\mathrm{H}_{1 \mathrm{~b}}$ : There is a significant relationship between adventure attributes as tourism core products and destination image.

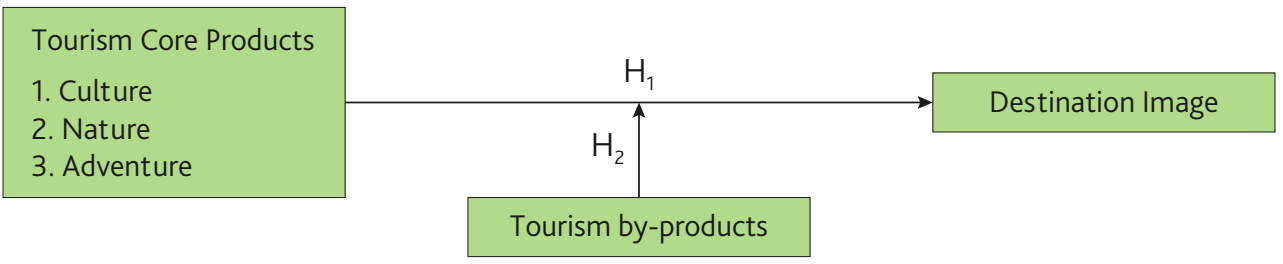

Figure 2. Conceptual Framework

Sources: Boukas, Ziakas, and Boustras (2012): Yuksel and Akgul, (2007) and; Tasci and Gartner (2007) 
$\mathrm{H}_{1 \mathrm{c}}$ : There is a significant relationship between nature attributes as tourism core products and destination image.

$\mathrm{H}_{2}$ : The tourism by-products moderates the relationship between tourism core products and destination image.

\section{Literature Review}

\section{Destination Image}

Beerli and Martin (2004) named three key factors that influence the image formation: 1) stimulus factors (information sources); 2) previous experience and distribution and 3) personal factors (psychological and social). Information sources are the main stimulus factors that affect the forming of cognitive perceptions and evaluations. Um and Crompton (1990) asserted that individuals form perceptual/cognitive evaluation of destination attributes subsequently to exposure to various information sources such as symbolic stimuli (promotional efforts through media), social stimuli (WOM and recommendations) and information acquired from previous visits.

Essentially, a primary image is formed through either personal experience or an actual visit to the destination. The destination image formed by the latter has the propensity to be more realistic and complex as opposed to the one formed by secondary sources of information (Baloglu, McCleary, 1999; Ryan, Cave, 2005). Phelps (1986) makes a proposition that the image formed by organic, induced and autonomous sources of information is dubbed as a secondary image. Another assertion by Beerli and Martin (2004) claimed that the secondary sources of information play a pertinent and crucial role in forming a cognitive dimension of the image. More importantly, Baloglu and McCleary (1999) stressed that the variety, the amount and the type of information sources are proxies for cognitive evaluation of images.

The process of image formation can be conceived as a continuum of separate agents or forces that generate a specific result either independently or in combination to form a destination image unique to an individual (Ryan, Cave, 2005). It is further affirmed that the detailed breakdown of agents is vital because destination selection itself is a process of narrowing alternatives from an initial opportunity set of all possible destinations to an evoked set of approximately three destinations. This contention is, indeed, in support of the general consumer behavior theory (Howard, Sheth, 1969). The consumer behavior theory claimed that destination images are imperative to the process of narrowing alternatives, and they act as pull factors toward the final selection.

\section{Tourism Core Products}

There are numerous ways of scholars looking at the tourism products. In the last four decades, tourism products are claimed as a collection of activities, services and benefits experienced by tourists that include destination facilities, destination attractions, price, accessibility and images (Medlik, Middleton, 1973; Smith, 1994; Xu, 2010) or the facilitating goods, explicit intangibles as well as implicit intangible elements (Wakefield, Blodgett, 1999; Xu, 2010). According to Jefferson and Lickorish (1988), tourism products are based on two perspectives: i) as a set of physical and service features as well as symbolic associations which are assumed to accomplish the needs and wants of the tourists and; ii) as satisfying activities at a preferred destination.

In the later year, scholars categorized tourism products into four levels; the core products, the facilitating products, the supporting products and augmented products (Kotler, Bowen, 1996; Oh, et al., 2004). The core products are the primary products or the main attraction being offered by a specific destination to tourists. These include the intangible products like experiences, excitement, nostalgia, peace and quiet (natural resources, scenery, climate, culture, ecology and historical architecture) or tangible products or manmade features that are built either by the government, tourism authorities, individuals and private sectors such as resorts, transportation, hotels, catering outlets and entertainment (Bosque, et al., 2009; Vassiliadis, 2008). Meanwhile, the facilitating products are associated with services and goods that must be together with the core products (Kotler, Bowen, 1996; Wakefield, Blodgett, 1999). Booking services are one of the examples of the facilitating products.

The third level is the supporting products or known as extra products or by-products. These products are the added value products to the core products being offered by a destination to distinguish it from other destination and are the standalone products including the local souvenirs, traditional and ethnic crafts, miniatures, food products and any merchandise that represents the local culture and other items purchased by tourists at a particular destination (Wakefield, Blodgett, 1999). The final level is the augmented products which are referred to the individual or tourists' perception, attitudes, participation and interaction with the service organizations (Smith, 1994).

Out of the four levels, the core tourism products are the major and the main attractions which selling by a specific destination to attract the tourists (Hanafiah, et al., 2016; Wong, Cheng, 2014). The core tourism products can be in the form of tangible and intangible elements or a combination of both (Akbar, et al., 2016). The tangible elements are the physical plant which includes scenery and attraction like cultural, adventure 
and natural resources, while intangible elements refer to related hospitality, services like safety, the friendliness of the local peoples as well as the uniqueness of the local by-products (Elliot, Papadopoulos, 2016; Xu, 2010). As this paper is looking at culture, adventure and nature as tourism core products the subsequent sections are specifically reviewed on these attributes.

\section{Cultural Tourism}

The importance of culture in tourism has been undeniable since the percentage of tourists seeking a cultural experience like visiting the cultural attraction and involving in various cultural activities are drastically increasing. According to the World Tourism Organization (WTO), more than forty percent of the international tourists from all parts of the world are among the "cultural tourists" (Richards, 2007). The Travel Industry Association of America (TIAA) reported that almost two-thirds of the United States adults chosen to visit the cultural sites or attractions when deciding to travel (Ghimire, 2013). This phenomenon manifests that culture is one an essential part of the tourism product (Horner, Swarbrooke, 2016; Richards, 2007).

A strong relationship between culture and tourist strengthen the attractiveness of the destinations, and this coined the term cultural tourism (McKercher, Du Cros, 2002; Richards, 2007; Stebbins, 1996). To date, $\mathrm{Du}$ Cros and McKercher (2015) postulates that cultural tourism is pronounced when tourists are traveling to a destination for experiencing and learns about the local traditions including food, the art, the folklore, the pilgrimage, historic sites and monuments without violating the respecting of the local community and the surrounding environment. Bali is a good example of cultural tourism destination in Asia which attracting a substantial number of international tourists (Hitchcock, 2009). The preservation of traditional culture is still very much alive in this island as its peoples have a strong spiritual root. Due to this, most of the international tourists are enjoying the original of culture showed by the people in this province (Hillman, et al., 2017; Hitchcock, 2009). Besides Bali, Brussels is one of the European cities that are popular with cultural tourism. A vast resource like museums, musicals, parks, theaters that come in bundles that popularize Brussels as a cultural city. Brussels is claimed to be the fourth most visited cultural cities in Europe and currently is the first ranking as the cultural city destination among the European cities (Liu, 2014; Richards, 2001). In the case of Sarawak, Hamzah (2004) and Bojei and Sahari (2015) stipulated that history (e.g. historical sites, museum, cultural centers, and galleries), lifestyle (e.g. indigenous people), architecture (e.g. longhouses, homestay), art, festival and cultural events, religion, music, dance, languages, be- liefs and culinary are among the dimensions of the cultural product in the state.

\section{Adventure Tourism}

Despite many interpretations, Hudson (2003) categorized adventure tourism into two that is hard and soft adventure tourism. The hard adventure tourism is associated with higher risk, and great challenge activities which required the individual tourist physically and mentally fits (Beard, et al., 2012). The activities include the rock climbing, canoeing, trekking, bungee jumping, wilderness survival as well as rafting. In contrast, the soft adventure tourism is referring to lower risk or fewer danger activities like hiking, bicycling, bird watching, riding, camping, surfing and cross-country skiing which require fewer skills and more comfortable regarding accommodation (Beard, et al., 2012).

As part of the ecotourism product (Addison, 1999), adventure tourism has gained attention from many countries around the globe, and it is tremendously commercialized (Pomfret, 2006). Adventure tourism, according to Hudson (2003) brings together to trav$\mathrm{el}$, sport and outdoor recreation with the focus are experiential engagement and the Adventure Travel and Tourism Association (2010) reported that the adventure travel is one of the fastest growing travel segments. Comparing among countries, the Western and Eastern Europe including the United Kingdom, Switzerland, Germany, Iceland, Slovak Republic and Romania, the United States, Canada, and New Zealand hold the top ranking while Thailand and Malaysia are the most popular among the ASEAN countries.

Taking one or two out of many examples, Romania which is located in Central and Southeastern Europe is popular with the adventure tourism (Gabriel, 2014). This fact is materialized through the existence of the Carpathian Mountains with rivers and heights that allow the practice of most of the following sports: Paragliding, Skiing, climbing, bungee-jumping, rafting, and kayaking. In the case of Sarawak, caving, jungle trekking is one the most popular rough activities which continuously pulling the international tourists (Sanggin, 2009). This is evident when Mulu and Niah Cave is successfully attracting a significant number of the international tourists throughout the year and these two and other caves manifestly portraying the image of Sarawak (Sarawak Tourism Board, 2014). Also, the local government's involvement in creating sustainable products and services also popularizes those activities in the state (Radzi, et al., 2014).

\section{Nature Tourism}

Nature tourism is concerned with any tourism that is dealing with experience directly correlated to natu- 
ral attractions (Commission for Environment Cooperation, 2000). The nature tourism encompasses very diverse forms include geo-tourism, extractive tourism, cycle tourism, nature retreats, cruise ship tourism, wildlife tourism as well as ecotourism (Balmford, et al., 2009). In the very beginning, nature tourism is associated with the outdoor travel, particularly in the isolated, remote and unique or scenic areas. However, the meaning is broadening when demand for educational subjects has become important part of it, thus, some scholars and the authorities denotes nature tourism as travelling to a destination to experience the natural places such as sightseeing, wildlife viewing, beaches, lakes, waterfalls, national parks, fishing and other nature activities (Fennell, 2014; Wearing, Neil, 1999)

Taking one example, as a subset of nature tourism, ecotourism growing popularity across the world caused more tourists in choosing destination that offers nature-based attractions (Balmford, et al., 2009; Stronza, 2001). According to a report by International Ecotourism Society or known as TIES, Ecotourism is about uniting conservation, and sustainable communities (Honey, et al., 2003). In precise words, it is associated with the responsible travel to natural areas that preserves the environment, a desire to learn and appreciate the unique flora and fauna and increases the well-being of the local people. In German, for instance, more than fifty percent of German tourists are choosing the natural attraction for their holiday and similarly with Finland, whereby more than forty percent of the population is engaged in nature trips. In fact, all the natural areas around the world are being promoted as ecotourism destinations (Fennell, 2014; Wood, 2002).

Being the home of the largest ethnic groups, Sarawak state is also the home for most exotic flora and fauna in Malaysia (Hamzah, 2004). As mentioned by Datuk Amar Abang Haji Abdul Rahman Zohari, the Minister of Tourism Sarawak, the National Parks continue to be an ideal destination among the international tourists (Sarawak Tourism Board, 2014). In 2015 , a total of 365,423 tourists visited the various $\mathrm{Na}$ tional Parks in the state and the Semenggoh Wildlife Centre recorded the highest number of visitors with 82,532 tourists, followed by Bako National Park with 45,431 tourists, Niah National Park $(24,213)$, Wind Caves $(23,653)$, Matang Wildlife Centre $(19,976)$ and Mulu National Park $(18,134)$ (Ministry of Tourism Sarawak, 2016).

\section{Tourism By-Products}

It is becoming a norm or trend when tourists are traveling to a particular destination; they will buy and purchase any tourism by- products for family members or friends (Elliot, Papadopoulos, 2016; Tangeland, Aas, 2011). In this sense, the tourism by- products is pronounced as a bundle of products of a particular destination besides the core products that represents the identity and image of a destination (Elliot, Papadopoulos, 2016). The local souvenir, ethnic crafts, miniatures and any merchandise that related to a destination are a compartment of the tourism by- products. These products reminded the journey of an individual and acted as a proof or memory of the scenic spots or cities they have visited (Kim, Littrell, 2001; Lin, Mao, 2015; Paraskevaidis, Andriotis, 2015; Swanson, Horridge, 2006; Wong, Cheng, 2014).

Gordon (1986) used the term tourism by- products as tourism souvenirs and divided it into five categories. The first is pictorial images containing postcards, poster, photographs, illustrated books, and pictures. The second type is a piece-of-the-rock that including rocks, grasses, shells, driftwood, pine cones and other that are relevant. The third type is symbolic shorthand including replicas of well-known attractions and miniaturized icon images which are mainly manufactured instead of natural material. Markers are the fourth type consisting of T-shirts, coffee mugs, coasters, which are relevant to a particular place, people, or event. Finally, the local products which include an array of indigenous objects such as foods, liquor, cooking utensils, clothing, and handicrafts (Noor, et al., 2012).

Many researchers have highlighted the importance of tourism by-products to a particular destination (Reisinger, Turner, 2003; Lin, Mao, 2015; Paraskevaidis, Andriotis, 2015). Reisinger and Turner (2003) stated that tourists are spent $2 / 3$ from their total cost of purchase of the local by-product of a particular destination while $1 / 5$ was spent when traveling internationally. In addition, Yin et al. (2017) argue that the local by-products in addition to tourism core products are part of numerous reasons tourists travel to a destination, and it could symbolize the image of that particular destination.

As previously mentioned, besides it tourism core products, Sarawak or the "Land of the Hornbills" is having an abundance of tourism by-products (Sarawak Tourism Board, 2014). This is either on pictorial images, piece-of-the-rock, symbolic shorthand, markers and the local products especially food related items. The 'Kek Lapis Sarawak (Sarawak Layered Cake,' 'Ikan Terubok Masin' (salted terubok fish), 'Tebaloi' (Sarawak traditional biscuit), Pua Kumbu (Sarawak mats) are some examples of the state's iconic products. According to Datuk Talip Zulpilip, the Assistant Tourism Minister of Sarawak, these by-products had been trademarked for the state since a long time ago (Borneo Post, 2014). 


\section{Methodology}

\section{Procedure and Sample}

A causal research design using a quantitative approach through a cross sectional study was applied with a selfreported and self-administered survey questionnaire. As this study centrally looking at Sarawak, Malaysia, the population and the unit analysis were among international tourists who visited Sarawak and experienced the state core tourism products including purchasing the local tourism by-products. Purposive and convenience sampling was applied in determining and approaching the respondents.

\section{Questionnaire Design}

The survey instrument includes five major sections with Section A solicit the information about respondent demographic information. Section B is dealing with Sarawak tourism core products (culture, adventure, and nature) while Section C is designed to measure the level of purchasing of the local tourism byproducts. Lastly, Section D specifically focuses on the international tourist's view toward Sarawak as destination image. Most items in all dimensions were replicated from the previous related studies with a few minor modifications of wording made to address specific needs of the current research or fit the tourism context. Specifically, items for section B were mostly adapted from Boukas, Ziakas, and Boustras (2012), section C from Yuksel and Akgul (2007) and section D from Tasci and Gartner (2007) with few developed by the researchers. Respondents were required to translate their view on a five type Likert scale ranging from 1 with "strongly disagree" to 5 with "strongly agree".

A pilot study was initially conducted to verify and confirm the reliability and validity of the items used. All comments and recommendations were considered, and some further changes were made before arriving at a final version of the survey instrument. For actual data collection, the questionnaire survey was administered by the researchers at the Kuching International Airport after obtaining permission from the airport management. The international tourists were approached at the departure hall seeking their assistance to being part of the study sample. With the full cooperation and commitment given by most of the international tourists, a total of 180 questionnaires were successfully distributed within 10-day survey period.

The first stage of the analysis involved testing the validity of the research variables. Three separate exploratory factor analyses were conducted for each variable. Principal component extraction with Varimax rotation was applied. The Kaiser-Meyer-Olkin (KMO) value was 0.79 and Bartlett's test was significant at the o.oo level. The criterion for the significance of factor loadings was set at 0.50 as per proposed by Hair Jr and Lukas (2014). Multiple regression was applied to answer the research hypotheses. Moderation analyses were conducted using techniques based on standard multiple regression and hierarchical regression analyses (Cohen, et al., 2013).

\section{Analysis and Results}

\section{Respondent profile}

Table 1 below presents the overall dimensions of the respondents' profiles such as gender, age, education level, marital status, occupation and country of origin.

Table 1. Respondent profile

\begin{tabular}{|c|c|c|}
\hline № & Demographic Profiles & Respondents \\
\hline \multirow{3}{*}{1} & \multicolumn{2}{|l|}{ Gender } \\
\hline & Male & 110 \\
\hline & Female & 70 \\
\hline \multirow{3}{*}{2} & \multicolumn{2}{|l|}{ Age } \\
\hline & 18-39 years old & 102 \\
\hline & 40-59 years & 78 \\
\hline \multirow{4}{*}{3} & \multicolumn{2}{|l|}{ Education level } \\
\hline & High school & 12 \\
\hline & Degree & 111 \\
\hline & Postgraduate degree & 57 \\
\hline \multirow{3}{*}{4} & \multicolumn{2}{|l|}{ Marital status } \\
\hline & Married & 108 \\
\hline & Single & 72 \\
\hline \multirow{5}{*}{5} & \multicolumn{2}{|l|}{ Occupation } \\
\hline & Administrative/clerical & 71 \\
\hline & Professional/businessman & 60 \\
\hline & Students & 31 \\
\hline & Semi-skilled worker & 18 \\
\hline \multirow{5}{*}{6} & \multicolumn{2}{|l|}{ Origin } \\
\hline & Asian continent & 90 \\
\hline & European continent & 50 \\
\hline & Australasian region & 30 \\
\hline & Others: America, Turkey & 10 \\
\hline
\end{tabular}

Note: $n=180$

The above frequency outputs show that the number of male tourists exceeded the female with 61.1 percent. Meanwhile, the senior age group between 40-59 years dominated the sample of tourist accounted around 56.7 percent as opposed to the adult groups with 43.3 percent. Also, 60.0 percent of the tourists were married while the rest were single. In term of education level, out of 180 visitors, 61.7 percent possessed at least 
a bachelor degree, followed by postgraduate degree with 31.7 percent and the remaining of 6.7 percent attends the high school.

Looking at their occupation, 39.4 percent of them were working in an administrative/ clerical, 33.3 percent were professional/businessman, 17.2 percent were students, and 10.o percent were in the semi-skills job and others. Meanwhile, in term of origin, the highest percentage of tourists involved in the survey were from the Asian continent (Chinese, Japanese, Korean and the South East Asian) accounted around 50.0 percent, followed by European continent with 27.8 percent and 16.7 percent $(n=30)$ from the Australasian region (Australia and New Zealand). The final 5.5 percent came from other countries including America, Turkey, and the Middle East.

\section{Relationship between Tourism Core Products and Sarawak Destination Image}

A single-step multiple regression was conducted to test the strength of the relationship between the tourism core products and destination image as the first hypothesis ( $\left.\mathrm{H}_{1}\right)$ of the study. The tourism core products dimension (culture, adventure, and nature) as the predictor and Sarawak destination image items as the criterion were entered into the equation separately as per proposed by Hair, Black, Babin, Anderson, and Tatham (1998). Table 2 displays the summary of the results.

Looking at Model 1, the independent or predictor: the core tourism products attributes accounted 40.5 percent $\left(R^{2}=.405, F\right.$-change $=121.348, p<$. o0o $\left.{ }^{* * *}\right)$ of the variance in Sarawak destination image dimension. The value of $\left(=.637, p<.000^{* * *}\right.$ indicated that the core tourism products attributes significantly and positively contribute to the Sarawak destination image. In other words, the core tourism products which include culture, adventure and nature influence the image of Sarawak as a tourism destination. With this, the hypothesis $1\left(\mathrm{H}_{1}\right)$ is therefore strongly supported.

In response to the results, the subsequent analysis was undertaken to grasp how strong is the relation- ship between each of the single sub-dimensions of the predictor variable with the destination image as the criterion variable. This step was taken to answer the three sub- hypotheses $\left(\mathrm{H}_{1 \mathrm{a}}, \mathrm{H}_{1 \mathrm{~b}}\right.$, and $\left.\mathrm{H}_{1 \mathrm{c}}\right)$.

\section{Relationship between Culture and Sarawak Destination Image}

For the first sub-hypothesis $\left(\mathrm{H}_{1 \mathrm{a}}\right)$, linear regression was conducted with culture attributes as predictor and the Sarawak destination image as a criterion. In other words, this analysis is to see how well the culture attributes contribute towards the Sarawak destination image. Model 2 displays the summary of the results. Model 2 shows culture as part of the tourism core product could explain 30.2 percent $\left(R^{2}=0.302\right.$, F-change $\left.=76.843, \mathrm{p}<.000^{* * *}\right)$ of the variance in the Sarawak destination image. The value of $(\beta=.549, \mathrm{p}$ $<.000^{* * *}$ ) demonstrated that culture has a strong significant contribution towards Sarawak destination image. Therefore, the first sub- hypothesis $\left(\mathrm{H}_{1 \mathrm{a}}\right)$ is strongly supported.

Many researchers support the above result. The majority of them postulated a strong relationship between culture and international tourists' motivation to travel (Hillman, et al., 2017). In the case of Sarawak, Hamzah (2004) and Bojei and Sahari (2015) stipulated that cultural tourism product strongly influenced the image of Sarawak tourist destination.

\section{Relationship between Adventure and Sarawak Destination Image}

The second sub-hypothesis evaluates the relationship between adventure as the predictor and the Sarawak destination image as the criterion variable. In particular, this analysis is to see how strong the influence of adventure on Sarawak destination image. Again, a linear regression was conducted, and the result is tabulated in Model 3. Looking at the Model 3, it signifies that adventure attributes as part of the Sarawak tourism core product were able to explain 23.6 percent $\left(R^{2}=.236, \mathrm{~F}\right.$-change $\left.=54.859, \mathrm{p}<.000^{* * *}\right)$ of the variance in the Sarawak destination image. The Beta val-

Table 2. Results of Linear Regression Analysis

\begin{tabular}{|l|c|c|c|c|}
\hline Predictors & $\begin{array}{c}\text { Model 1 } \\
\mathrm{H}_{1}\end{array}$ & $\begin{array}{c}\text { Model 2 } \\
\mathrm{H}_{1 \mathrm{a}}\end{array}$ & $\begin{array}{c}\text { Model 3 } \\
\mathrm{H}_{1 \mathrm{~b}}\end{array}$ & $\begin{array}{c}\text { Model 4 } \\
\mathrm{H}_{1 \mathrm{c}}\end{array}$ \\
\hline Model Variables: & $\begin{array}{c}\text { Core Tourism } \\
\text { Products }\end{array}$ & Culture & Adventure & Nature \\
\hline Destination Image & $0.637^{* * *}$ & $0.549^{* * *}$ & $0.485^{* * *}$ & $0.458^{* * *}$ \\
\hline$R^{2}$ & 0.405 & 0.302 & 0.236 & 0.210 \\
Adj. $R^{2}$ & 0.402 & 0.298 & 0.231 & 0.206 \\
$R^{2}$ Change & 0.405 & 0.302 & 0.236 & 0.210 \\
F-Change & $121.348^{* * *}$ & $76.843^{* * *}$ & $54.859^{* * *}$ & $47.324^{* * *}$ \\
\hline
\end{tabular}

Note: ${ }^{*} p<0.05,{ }^{* *} p<0.01,{ }^{* * *} p<0.001$ 
ue $\left(\beta=.483, \mathrm{p}<.000^{* *}\right)$ indicated that culture as part of core tourism products attributes significantly and positively influence the image of Sarawak as a tourism destination. Hence, the second sub-hypothesis $\left(\mathrm{H}_{1 \mathrm{~b}}\right)$ is strongly supported.

The above result is in line with Sanggin (2009), in which he claimed that caving, jungle trekking is one the most popular rough activities which continuously pulling the international tourists. On the other hand, Gabriel (2014) and Pomfret (2006) proposed that Adventure tourism has gained attention from many countries around the globe, and it is tremendously commercialized in destination marketing.

\section{Relationship between Nature and Sarawak Destination Image}

For the third sub-hypothesis, the predictor variable comprised of nature against the Sarawak destination image as a criterion variable as depicted in Model 4. The result shows that nature as part of tourism core product attributes was able to explain 21.0 percent $\left(R^{2}\right.$ $=.210, \mathrm{~F}-$ Change $\left.=47.324, \mathrm{p}<.000^{* * *}\right)$ of the variance in the Sarawak destination image. Again, it evidently shows that nature attributes $\left(\beta=.458 \mathrm{p}<0.000^{* * *}\right)$ was also found to have a significant impact and positive influence on the Sarawak destination image. Thus, the hypothesis $1\left(\mathrm{H}_{1 \mathrm{c}}\right)$ is supported.

The result above shows that nature attributes of a destination posit a significant effect on the tourist destination image. Balmford et al. (2009) supported the above notion by also claiming that ecotourism growing popularity caused more tourists choosing the nature-based attractions. Similarly, Fennell (2014) also claimed that the image of a destination is affected by the availability of natural areas. Moreover, being the home of the largest ethnic groups, Sarawak state is also the home for most exotic flora and fauna in $\mathrm{Ma}$ laysia (Hamzah, 2004).

\section{Moderating Effect of the Local Tourism By-products}

The second main hypotheses are to investigate how well and to what extent the levels of purchasing of the local by-products moderate the relationship between tourism core products (culture, adventure, and nature) and Sarawak destination image. In this analysis, the predictors comprised the attributes of Sarawak tourism core products as the independent variable and the levels of purchasing the local by-products dimensions as a mediator, while criterion referred to the Sarawak destination image dimensions. Moderated regression analysis as the recommended method for testing interaction effects, were used (Cohen, et al., 2013). The results of hierarchical analysis using multiple regression analysis were exhibited in Table 3.
Table 3. Results of Hierarchical Analysis

\begin{tabular}{|l|l|l|}
\hline Predictor & $\begin{array}{l}\text { Model 1 } \\
\text { Std. } \beta\end{array}$ & $\begin{array}{l}\text { Model 2 } \\
\text { Std. } \beta\end{array}$ \\
\hline $\begin{array}{l}\text { Step 1: DV: Destination } \\
\text { Image }\end{array}$ & & \\
\hline $\begin{array}{l}\text { Core Tourism Products } \\
\text { Attributes }\end{array}$ & $0.637^{* * *}$ & \\
\hline $\begin{array}{l}\text { Step 2: DV: Destination } \\
\text { Image }\end{array}$ & & \\
\hline $\begin{array}{l}\text { a. Core Tourism Products } \\
\text { Attributes } \\
\text { b. Tourism By-Products }\end{array}$ & & $0.318^{* * *}$ \\
\hline $\begin{array}{l}\text { R2 } \\
\text { Adj. } R^{2}\end{array}$ & $0.242^{* * *}$ \\
$\begin{array}{l}R^{2} \text { Change } \\
\text { F-Change }\end{array}$ & 0.405 & 0.497 \\
\hline
\end{tabular}

Note: ${ }^{*} p<0.05,{ }^{* *} p<0.01,{ }^{* * *} p<0.001$

The moderating effects were calculated using multiple hierarchical linear regressions whereby main effects are presented in the first step and interactions in the second step. Looking at Model 1, the attributes of Sarawak tourism core products able to explain the 40.5 percent $\left(R^{2}=.405\right.$, F-change $\left.=121.348, \mathrm{p}<.001\right)$ of the variation in the destination image dimension. The value of $(=.637, p<$. ooo demonstrated that attributes of Sarawak core tourism products had given a substantial impact on the image of Sarawak as a tourism destination among the international tourists.

In the second step of hierarchical multiple regression (Model 2), the level of purchasing the local by-products as moderator was entered as another independent variable to influence the dependent variable. The levels of purchasing of the local by-products dimensions explain the additional 9.1 percent $\left(R^{2}\right.$ Change $\left.=9.1 \%\right)$ as a moderating to the relationship between Sarawak tourism core products toward it tourism image. The beta value $(\beta=.318, p<.001)$ of levels of purchasing the local by-products and the beta value $(\beta=.538, p<.001)$ of destination image indicate that the local by-products in addition to tourism core products contribute to the Sarawak destination image. Hence, the second hypothesis $\left(\mathrm{H}_{2}\right)$ is strongly supported.

It is a norm that tourists will spend for their family members or friends during traveling (Elliot, Papadopoulos, 2016; Tangeland, Aas, 2011). In term of purchase behavior, the tourism by- products is the most purchased item besides the core products (Elliot, Papadopoulos, 2016). These products acted as a proof or memory of the scenic spots or cities they have visited, in which generate the destination image (Lin, Mao, 2015; Paraskevaidis, Andriotis, 2015; Wong, Cheng, 2014). 


\section{Conclusion}

This study highlighted the role of niche tourism products in destination development. This study also provides evidence that tourism core product is necessary for amplification of a destination image. The research findings indicate that Sarawak has a lot of valuable resources in the eye of the international tourists through its tourism core products namely marine, nature and culture. These tourism products offer destinations specifically Sarawak an opportunity to differentiate and reposition themselves to a more distinct, lucrative market. However, despite having a thousand wonderful products, it would not be meaningful if there is no mutual relationship and good cooperation from all parties or the state image will go nowhere. Therefore, there is a need to sustain and continuously improve the existing tourism products including the local by-products which will uplift the image of Sarawak as a tourist destination in the eyes of the international tourists.

\section{Theoretical Contribution}

From the summary of the findings, no doubt that Sarawak as a state has rich and valuable tourism core products which comprise of culture, adventure, and nature. These three tourism core products are attracting not only to the local but the international tourists as well. This result is evident when most of the international tourists perceived that this land of handbills is having a vast, unique and exciting culture, adventure and nature attractions. Their positive perception is turned into various activities related to those attributes. In fact, the magnificent culture, adventure, and nature perceived by the international tourist undeniable building and strengthening the image of Sarawak as a tourist destination.

As expected and in line with other researchers' findings, culture is one of the pillars of the tourism in the state. The result of this present study indicates that the majority of the international tourists enjoyed the cultural activities the most. This conjecture is supported through all the proposed main and sub- hypotheses of the study. In addition to the above positive results, the most remarkable findings from this study are that the local by-products also contributed and increased the image of Sarawak. Despite experiencing the tourism core products, the Sarawak local by-products also clasp the attention of the international tourists to visit the state, and without a doubt, they purchased and spent a lot on it during their holiday on various types of local by-products.

\section{Practical Contribution}

This study proves that the impact of tourism by-product on destination image is undeniable. Therefore, the state government through the Ministry of Tourism Sarawak and the Sarawak Tourism Board with other associations like the Sarawak Craft Arts and Craft Heritage Center, the Sarawak Craft Council and other related bodies should not ignore the role of the local by-products in lifting the image of the state. The responsible bodies need to disseminate information on the importance of the local by-products to handcraft sellers as well as in the tourism industry for the sake of the state image.

Other initiatives also can be done by responsible authorities by creating awareness to the tour operators. Besides bringing the tourists to the three Sarawak tourism core attractions, the tour operators can aid the handicrafts and souvenir sellers by taking them to shop at the respective premises. Creating awareness of the availability of the local by-products can also be done through a variety of promotional materials such as books, brochures, booklets, postcards, movies, events, and broadcasting. By doing so, it will not only directly strengthen the tourism core products, but indirectly it also promotes the Sarawak local by-products to both international tourists as well as to entire of the world.

\section{Future Studies and Limitations}

This study entails several limitations. First, this study only focusses on three specific core products: culture, nature, and adventure, in which neglect other core and complementary tourism attribute from the study framework. Therefore, further studies should investigate the nature of this relationship using different products. Also, future study should assess and confirm this study framework using the advance Structural Equation Modeling.

\section{References}

Addison, G. 1999. Adventure tourism and ecotourism. Adventure Programming 2, 415-430.

Agapito, D., Oom do Valle, P., da Costa Mendes, J. 2013. The cognitive-affective-conative model of destination image: A confirmatory analysis. Journal of Travel \& Tourism Marketing 30-5, 471-481.

Adventure Travel and Tourism Association. 2010. Advance Tourism Market Report. Available at http:// www.adventuretravel.biz/

Akbar, S. N. A., Ridzuan, N. A., Zahari, M. S. M., Hanafiah, M. H. 2016. Dimensional structure of rural tourism cultural attributes: A Confirmatory Factor Analysis (CFA) approach. Heritage, Culture, and Society: Research agenda and best practices in the hospitality and tourism industry, 421.

Balmford, A., Beresford, J., Green, J., Naidoo, R., Walpole, M., Manica, A. 2009. A global perspective 
on trends in nature-based tourism. PLoS Biol 7-6, e1000144.

Baloglu, S., McCleary, K. W. 1999. A model of destination image formation. Annals of Tourism Research 26-4, 868-897.

Ban, J., Ramsaran, R. R. 2017. An Exploratory Examination of Service Quality Attributes in the Ecotourism Industry. Journal of Travel \& Tourism Marketing 34-1, 132-148.

Beard, C., Swarbrooke, J., Leckie, S., Pomfret, G. 2012. Adventure Tourism: Routledge.

Beerli, A., Martin, J. D. 2004. Factors influencing destination image. Annals of Tourism Research 31-3, 657-681.

Bojei, J., Sahari, M. 2015. Empirical Investigation on the Determinants of Marketing Sarawak's Heritage as Tourists Destination. Paper presented at the Proceedings of the 1996 Multicultural Marketing Conference.

Bornhorst, T., Ritchie, J. B., Sheehan, L. 2010. Determinants of tourism success for DMOs \& destinations: An empirical examination of stakeholders' perspectives. Tourism Management 31-5, 572-589.

Bosque, I. R. d., Martín, H. S., Collado, J., Salmones, M. d. M. G. d. 2009. A framework for tourist expectations. International Journal of Culture, Tourism and Hospitality Research 3-2, 139-147.

Brijs, K., Bloemer, J., Kasper, H. 2011. Country-image discourse model: Unraveling meaning, structure, and function of country images. Journal of Business Research 64-12, 1259-1269.

Budnarowska, C. 2012. 8 Fashion retail formats as tourist retail destinations and attractions. Tourism and Retail: The Psychogeography of Liminal Consumption 24, 169.

Buhalis, D. 2000. Marketing the competitive destination of the future. Tourism Management 21-1, 97-116.

Chen, C.-F., Phou, S. 2013. A closer look at destination: Image, personality, relationship and loyalty. Tourism Management 36, 269-278.

Chin, C.-H., Lo, M.-C., Ramayah, T. 2016. Rural Tourism Sustainable Management and Destination Marketing Efforts: Key Factors from Communities' Perspective. Journal of Sustainable Development 9-4, 179-197.

Cohen, J., Cohen, P., West, S. G., Aiken, L. S. 2013. Applied multiple regression/correlation analysis for the behavioral sciences. Routledge.

Du Cros, H., McKercher, B. 2015. Cultural Tourism (Vol. 2): Routledge New York, NY.

Elliot, S., Papadopoulos, N. 2016. Of products and tourism destinations: An integrative, cross-national study of place image. Journal of Business Research 69-3, 1157-1165.

Fennell, D. A. 2014. Ecotourism. Routledge.
Gabriel, S. 2014. Gorj-Tourism Potential Valued For Romania. Annals-Economy Series, 64-67.

Gallarza, M. G., Saura, I. G., García, H. C. 2002. Destination image: Towards a conceptual framework. Annals of Tourism Research 29-1, 56-78.

Ghimire, K. B. 2013. The native tourist: Mass tourism within developing countries. Routledge.

Gordon, B. 1986. The souvenir: Messenger of the extraordinary. The Journal of Popular Culture 20-3, 135-146.

Hair, J. F., Black, W. C., Babin, B. J., Anderson, R. E., Tatham, R. L. 1998. Multivariate Data Analysis (Vol. 5), Prentice hall Upper Saddle River, NJ.

Hair Jr, J. F., Lukas, B. 2014. Marketing research, McGraw-Hill Education Australia.

Hamzah, A. 2004. Policy and planning of the tourism industry in Malaysia. Paper presented at the The 6th. ADRF General Meeting.

Hanafiah, M. H., Hemdi, M. A., Ahmad, I. 2016. Tourism destination competitiveness: Towards a performance-based approach. Tourism Economics 22-3, 629-636.

Hillman, P., Moyle, B. D., Weiler, B. 2017. Perceptions of Impacts and Development in a Cultural Tourism Hub: Ubud, Bali. Balancing Development and Sustainability in Tourism Destinations. Springer, 57-66 pp.

Hitchcock, M. 2009. Tourism in Southeast Asia: Challenges and New Directions, Nias Press.

Honey, M., Thullen, S., Hebert, R. Dugan, D. 2003. Rights and Responsibilities: A Compilation of Codes of Conduct for Tourism and Indigenous \& Local Communities. Center on Ecotourism and Sustainable Development/The International Ecotourism Society.

Horner, S., Swarbrooke, J. 2016. Consumer behaviour in tourism. Routledge.

Hosany, S., Ekinci, Y., Uysal, M. 2007. Destination image and destination personality. International Journal of Culture, Tourism and Hospitality Research 1-1, 62-81.

Howard, J. A., Sheth, J. N. 1969. The theory of Buyer Behavior (Vol. 14): Wiley New York.

Hudson, S. 2003. Sport and adventure tourism. Routledge.

Jamaludin, M., Johari, S., Aziz, A., Kayat, K., Yusof, A. R. M. 2012. Examining structural relationship between destination image, tourist satisfaction and destination loyalty. International Journal of Independent Research and Studies 1-3, 89-96.

Jefferson, A., Lickorish, L. J. 1988. Marketing tourism. A practical guide. Longman Group UK Ltd.

Kim, S., Littrell, M. A. 2001. Souvenir buying intentions for self versus others. Annals of Tourism Research 28-3, 638-657. 
Kotler, B., Bowen, J., Makens, J.C. 1999. Marketing for Hospitality and Tourism. Prentice Hall International Ic, New Jersey.

Lin, L., Mao, P.-C. 2015. Food for memories and culture-A content analysis study of food specialties and souvenirs. Journal of Hospitality and Tourism Management 22, 19-29.

Liu, Y.-D. 2014. Cultural events and cultural tourism development: Lessons from the European Capitals of Culture. European Planning Studies 22-3, 498-514.

McCartney, G., Butler, R., Bennett, M. 2008. A strategic use of the communication mix in the destination image-formation process. Journal of Travel Research 47-2, 183-196.

McKercher, B., Du Cros, H. 2002. Cultural tourism: The partnership between tourism and cultural heritage management, Routledge.

Medlik, S., Middleton, V. T. 1973. Product formulation in tourism. Tourism and Marketing 13, 173-201.

Mehmetoglu, M., Normann, Ø. 2013. What influences tourists' overall holiday experience? Tourism company products versus destination products. European journal of Tourism Research 6-2, 183.

Ministry of Tourism Sarawak. 2016. The statistic of tourist arrival to Sarawak. Avalable at http://www. Mot.Sarawak.gov.my/

Musa, G., Thirumoorthi, T. 2016. Tourism in Malaysia. In: Hall, M., Page, S. [eds.] The Routledge Handbook of Tourism in Asia. Routledge, London

Noor, A. M., Remeli, M. R. B., Hanafiah, M. H. M. 2012. International tourist acceptance of Sabah's gastronomy product. Current Issues in Hospitality and Tourism. Research and Innovations 57, 377.

Oh, H., Kim, B.-Y., Shin, J.-H. 2004. Hospitality and tourism marketing: recent developments in research and future directions. International Journal of Hospitality Management 23-5, 425-447.

Ortega, E., Rodríguez, B. 2007. Information at tourism destinations. Importance and cross-cultural differences between international and domestic tourists. Journal of Business Research 6o-2, 146-152.

Paraskevaidis, P., Andriotis, K. 2015. Values of souvenirs as commodities. Tourism Management 48, 1-10.

Phelps, A. 1986. Holiday destination image-the problem of assessment: An example developed in Menorca. Tourism Management 7-3, 168-18o.

Pike, S., Page, S. J. 2014. Destination Marketing Organizations and destination marketing: A narrative analysis of the literature. Tourism Management 41, 202-227.

Pomfret, G. 2006. Mountaineering adventure tourists: A conceptual framework for research. Tourism Management 27-1, 113-123.
Prebensen, N. K. 2007. Exploring tourists' images of a distant destination. Tourism Management 28-3, 747-756.

Radzi, S. M., Bakhtiar, M. F. S., Mohi, Z., Zahari, M. S. M., Sumarjan, N., Chik, C. T., Anuar, F. I. [eds.], 2014 Theory and Practice in Hospitality and Tourism Research. CRC Press. Netherlands.

Reisinger, Y., Turner, L. 200o. Japanese tourism satisfaction: Gold coast versus Hawaii. Journal of Vacation Marketing 6-4, 299-317.

Reisinger, Y., Turner, L. W. 2003. Cross-cultural behaviour in tourism: Concepts and analysis. Elsevier.

Richards, G. 2001. The development of cultural tourism in Europe. Cultural attractions and European tourism, 28.

Richards, G. 2007. Cultural Tourism: Global and local perspectives. Psychology Press.

Roth, K. P., Diamantopoulos, A. 2009. Advancing the country image construct. Journal of Business Research 62-7, 726-740.

Ryan, C., Cave, J. 2005. Structuring destination image: A qualitative approach. Journal of Travel Research 44-2, 143-150.

Sanggin, S. E. 2009. Community involvement in culture and nature tourism in Sarawak. Akademika 77, 149-165.

Sarawak Tourism Board. 2014. Sarawak Tourism Products. Available at: http://www.Sarawaktourism.com/

Smith, S. L. 1994. The tourism product. Annals of Tourism Research 21-3, 582-595.

Stebbins, R. A. 1996. Cultural tourism as serious leisure. Annals of Tourism Research 23-4, 948-950.

Stronza, A. 2001. Anthropology of tourism: Forging new ground for ecotourism and other alternatives. Annual Review of Anthropology 30-1, 261-283.

Swanson, K. K., Horridge, P. E. 2006. Travel motivations as souvenir purchase indicators. Tourism Management 27-4, 671-683.

Tangeland, T., Aas, Ø. 2011. Household composition and the importance of experience attributes of nature based tourism activity products-A Norwegian case study of outdoor recreationists. Tourism Management 32-4, 822-832.

Tasci, A. D., Gartner, W. C. 2007. Destination image and its functional relationships. Journal of travel research 45-4, 413-425.

Tasci, A. D., Gartner, W. C., Tamer Cavusgil, S. 2007. Conceptualization and operationalization of destination image. Journal of Hospitality \& Tourism Research 31-2, 194-223.

Tasci, A. D., Kozak, M. 2006. Destination brands vs destination images: Do we know what we mean? Journal of Vacation Marketing 12-4, 299-317. 
Um, S., Crompton, J. L. 1990. Attitude determinants in tourism destination choice. Annals of Tourism Research 17-3, 432-448.

Usakli, A., Baloglu, S. 2011. Brand personality of tourist destinations: An application of self-congruity theory. Tourism Management 32-1, 114-127.

Vassiliadis, C. A. 2008. Destination product characteristics as useful predictors for repeat visiting and recommendation segmentation variables in tourism: a CHAID exhaustive analysis. International Journal of Tourism Research 10-5, 439-452.

Volkov, S. 2010. St Petersburg: A Cultural History. Simon and Schuster.

Wakefield, K. L., Blodgett, J. G. 1999. Customer response to intangible and tangible service factors. Psychology \& Marketing 16-1, 51-68.

Wang, C. L., Li, D., Barnes, B. R., Ahn, J. 2012. Country image, product image and consumer purchase intention: Evidence from an emerging economy. International Business Review 21-6, 1041-1051.

Wearing, S., Neil, J. 1999. Ecotourism: Impacts. Potentials and Possibilities Butterworth-Heinemann.
White, C. J. 2014. Ideal standards and attitude formation: A tourism destination perspective. International Journal of Tourism Research 16-5, 441-449.

Wong, I. A., Cheng, M. 2014. Exploring the effects of heritage site image on souvenir shopping attitudes: The moderating role of perceived cultural difference. Journal of Travel \& Tourism Marketing 31-4, 476-492.

Wood, M. 2002. Ecotourism: Principles, practices and policies for sustainability. UNEP.

$\mathrm{Xu}$, J. B. 2010. Perceptions of tourism products. Tourism Management 31-5, 607-610.

Yin, C.-Y., Poon, P., Su, J.-L. 2017. Yesterday once more? Autobiographical memory evocation effects on tourists' post-travel purchase intentions toward destination products. Tourism Management 61, 263-274.

Yüksel, A., Akgül, O. 2007. Postcards as affective image makers: An idle agent in destination marketing. Tourism Management 28-3, 714-725.

Zhang, H., Fu, X., Cai, L. A., Lu, L. 2014. Destination image and tourist loyalty: A meta-analysis. Tourism Management 40, 213-223. 